\title{
A new pathogenic virus in the Caribbean spiny lobster Panulirus argus from the Florida Keys
}

\author{
Jeffrey D. Shields ${ }^{1, *}$, Donald C. Behringer $\mathrm{Jr}^{2}$ \\ ${ }^{1}$ Virginia Institute of Marine Science, The College of William \& Mary, Gloucester Point, Virginia 23062, USA \\ ${ }^{2}$ Department of Biological Sciences, Old Dominion University, Norfolk, Virginia 23529, USA
}

\begin{abstract}
A pathogenic virus was diagnosed from juvenile Caribbean spiny lobsters Panulirus argus from the Florida Keys. Moribund lobsters had characteristically milky hemolymph that did not clot. Altered hyalinocytes and semigranulocytes, but not granulocytes, were observed with light microscopy. Infected hemocytes had emarginated, condensed chromatin, hypertrophied nuclei and faint eosinophilic Cowdry-type-A inclusions. In some cases, infected cells were observed in soft connective tissues. With electron microscopy, unenveloped, nonoccluded, icosahedral virions $(182 \pm$ $9 \mathrm{~nm} \mathrm{SD)}$ were diffusely spread around the inner periphery of the nuclear envelope. Virions also occurred in loose aggregates in the cytoplasm or were free in the hemolymph. Assembly of the nucleocapsid occurred entirely within the nucleus of the infected cells. Within the virogenic stroma, blunt rod-like structures or whorls of electron-dense granular material were apparently associated with viral assembly. The prevalence of overt infections, defined as lethargic animals with milky hemolymph, ranged from 6 to $8 \%$ with certain foci reaching prevalences of $37 \%$. The disease was transmissible to uninfected lobsters using inoculations of raw hemolymph from infected animals. Inoculated animals became moribund 5 to $7 \mathrm{~d}$ before dying and they began dying after 30 to $80 \mathrm{~d}$ post-exposure. The new virus is apparently widespread, infectious, and lethal to the Caribbean spiny lobster. Given the pathogenic nature of the virus, further characterization of the disease agent is warranted.
\end{abstract}

KEY WORDS: Crustacea $\cdot$ Disease $\cdot$ Decapoda $\cdot$ Hemocyte $\cdot$ Pathology $\cdot$ Viral assembly $\cdot$ Herpes-like $\cdot$ Iridovirus Resale or republication not permitted without written consent of the publisher

\section{INTRODUCTION}

The Caribbean spiny lobster Panulirus argus supports the single most valuable fishery in Florida and is heavily exploited by both commercial and recreational fishers. In 1999, 7.5 million pounds ( US\$20 to 23 million) of spiny lobsters were landed in Florida with approximately $90 \%$ of the fishery occurring within the Florida Keys (Florida Marine Research Institute 2001: Spiny lobster fact sheet; http://floridamarine.org/ features). The recreational fishery may account for an additional $20 \%$ of the annual catch in a short $2 \mathrm{~d}$ opening prior to the start of the commercial season. For years, concerns about the sustainability of this important resource have focused on over-fishing and deterioration of nursery habitats. Yet, few studies have focused on diseases of the spiny lobster or the potential for negative impacts on their populations.

Palinurid lobsters in the genera Panulirus spp., Palinurus spp. and Jasus spp. have few reported diseases (for review see Evans \& Brock 1994, Evans et al. 2000). Until now, viral infections have never been conclusively demonstrated. Shell disease from chitinoclastic bacteria can cause lesions around the tail and uropods of infected animals resulting in poor marketability (Sinderman \& Rosenfield 1967, Alderman 1973, Iversen \& Beardsley 1976, Booth 1988). Systemic infections of Vibrio spp. have occasionally developed in lobsters subjected to increased temperature, holding stress, or poor water quality (Chong \& Chao 1986, Diggles et al. 2000). A presumed bacterial infection called hepatopancreatic disease occurred in larval lobsters used in 
life history studies, and the condition was treated with streptomycin (Kittaka \& Abrunhosa 1997). Filamentous bacteria, presumably Leucothrix mucor, indicative of poor water quality or stress, have been observed on the gills and eggs of Jasus edwardsii (J.D.S. unpubl. data). Additionally, in experimental infections, Aerococcus viridans, the causative agent of gaffkemia in clawed lobsters, is pathogenic to Panulirus interruptus (Schapiro et al. 1974) and may occur naturally in $P$. argus (Bobes et al. 1988). The later stages of gaffkemia infection cause 'red tail' in clawed lobsters, a syndrome quite different from that observed in viral infections. Fungal infections have been reported on the carapace (Alderman 1973, McAleer 1983, Evans et al. 2000), gills (cf. Didymaria spp., Penicillium spp.; Sordi 1958, B. Diggles, NIWA, New Zealand, pers. comm.) and larvae (Kitancharoen \& Hatai 1995). A microsporidian was pathogenic in the muscles of $P$. argus, $P$. cygnus and $P$. ornatus, but infections were extremely rare (Bach \& Beardsley 1976, Dennis \& Munday 1994). At least 3 helminths use spiny lobsters as intermediate hosts: a microphallid trematode infects the ovaries of adult P. cygnus (Deblock et al. 1990), a tetraphyllidean cestode occurs in the foregut of several species of spiny lobsters from the Great Barrier Reef (J.D.S. unpubl. data), and a nematode infects the larvae and juveniles of $J$. edwardsii (Brett cited in Booth 1988). Finally, at least 2 egg predatory nemerteans, Carcinonemertes spp. (Campbell et al. 1989, Shields \& Kuris 1990) and amphipods, cf. Parapleustes spp. (J.D.S. pers. obs.), infest the egg clutches of at least 3 species of spiny lobsters.

Here we report the first naturally occurring pathogenic virus to be identified from a lobster. In 1999 and 2000, while sampling juvenile spiny lobster populations in the Florida Keys, one of us (D.C.B.) discovered lethargic, moribund animals whose hemolymph appeared 'thin' and 'milky,' rather than its normally transparent color, and which did not clot. The hemolymph was negative for Gram-negative bacteria, but the histopathology showed nuclear hypertrophy with diffuse Cowdry-type A viral inclusions in infected hemocytes. In heavily infected individuals, virtually all of the host's hyalinocytes and semigranulocytes were destroyed; granulocytes were not infected. Our objectives were to identify the causative agent, describe the histopathology of the infection, and report initial findings on the prevalence of the disease in the Florida Keys.

\section{MATERIALS AND METHODS}

Juvenile spiny lobsters were collected from 14 $\left(25 \mathrm{~m}^{2}\right)$ sites located throughout western Florida Bay adjacent to the middle and lower Florida Keys. Each site was located in hard-bottom habitat, the preferred nursery habitat of juvenile spiny lobsters in the Florida Keys (Butler et al. 1995, Herrnkind et al. 1997). Sites were surveyed by 2 divers seasonally during the winter (January to March) and summer (June to August). Survey and site details will be reported elsewhere D.C.B et al. unpubl. data). During the surveys, all lobsters were captured and brought aboard the research vessel. Moribund animals were returned to the laboratory for observation and confirmation of disease. Healthy animals were returned to their habitat. To verify the presence of the virus, hemolymph and other tissues from several lobsters were fixed and processed for histology as described below.

At present there are no crustacean cell lines available for viral culture. Therefore, the virus was maintained in the laboratory by serial passage of infected hemolymph into uninfected lobsters. Uninfected lobsters used for experiments were collected from outside the designated survey sites and were held for up to $1 \mathrm{wk}$ prior to treatment to insure acclimation and absence of overt diseases. During the experiments, lobsters were fed shrimp and squid ad libitum every 2 to $3 \mathrm{~d}$ and held individually in $38 \mathrm{l}$ aquaria with flowthrough ambient seawater. Only juvenile lobsters, 25 to $55 \mathrm{~mm}$ carapace length (CL), were used in inoculation trials. Infected lobsters were housed separately and used as hemolymph donors to inject naïve hosts ( 0.1 to $0.2 \mathrm{ml}$ hemolymph/host). Injections were given in the arthrodial membrane at the juncture of the basis and ischium of the 5th walking leg. We have maintained the virus for over 2 yr using this method with no apparent loss of pathogenicity.

Two inoculation trials consisted of injecting uninfected lobsters with hemolymph from infected donors. In Trial I, $0.1 \mathrm{ml}$ infected hemolymph was inoculated separately into one of the limb joints of 10 uninfected lobsters using a sterile 27 gauge needle. In Trial II, $0.2 \mathrm{ml}$ infected hemolymph was inoculated separately into 11 uninfected lobsters. In all cases, a 70\% ethanol spray was used to sterilize the area around the injection site. To verify the presence of the virus, hemolymph and other tissues from the donor lobsters were fixed and processed for histology as described below. For the control group, uninfected hemolymph was collected from healthy lobsters and treated as above for injection into uninfected lobsters. In both trials, hemolymph smears were taken biweekly from challenge and control lobsters. Animals were monitored daily for morbidity and mortality.

Dissections were performed on uninfected control animals and animals showing increasing signs of morbidity. For histology, hepatopancreas, heart, gill, muscle, foregut, hindgut, and, in some cases, hemopoietic tissues were dissected and fixed in $10 \%$ neutral 
buffered Formalin, with the exception of a few animals fixed with Bouins solution, then processed through routine paraffin procedures using Harris hematoxylin and eosin Y (e.g. Humason 1979).

For diagnosis of the virus in hemolymph, blood samples were stained with either Harris hematoxylin and eosin or with Castañeda's methylene blue protocols (Humason 1979). Briefly, hemolymph was drawn into ice-cold $10 \%$ neutral-buffered Formalin at a ratio of 5:1 or 10:1 fixative to hemolymph. Fixed samples were stored at $4^{\circ} \mathrm{C}$. For processing, 1 to 2 drops of fixed hemolymph was smeared onto a poly-L-lysinecoated microslide which was then air-dried, fixed in $100 \%$ methanol, and stained using minor modifications to the protocols. Histology gave superior results for diagnosis.

The hepatopancreas, connective tissue, gill, and hemopoietic tissue from 4 infected and one uninfected lobster were prepared for transmission electron microscopy (TEM) using $3 \%$ glutaraldehyde in $0.2 \mathrm{M}$ sodium cacodylate buffer. Similar tissues from 2 different infected and one different control animal were fixed in $3 \%$ glutaraldehyde containing $0.2 \mathrm{M}$ sodium cacodylate augmented with $30 \mathrm{mg} \mathrm{ml}^{-1} \mathrm{NaCl}$ and $20 \mathrm{ug} \mathrm{ml}^{-1}$ $\mathrm{CaCl}_{2}$, at pH 7.0 as per Factor \& Naar (1985). The latter gave superior results for visualizing viral and host cell morphologies. After fixation, tissues were washed 3 times in buffer and postfixed in 1\% osmium tetroxide in buffer. Samples were then processed through an ethanol dehydration, en bloc stained with uranyl acetate, dehydrated further with propylene oxide, infiltrated through several changes of propylene oxide in various ratios with Spurr's resin, and finally embedded in Spurr's resin. Sections were cut on a ReichertJung ultramicrotome $\mathrm{E}$, processed through a routine lead citrate stain, and observed with a Zeiss CEM-902 TEM.

\section{RESULTS}

\section{Light microscopy}

Heavily infected animals exhibited lethargy, inability to right themselves, infrequent tremors, and milky or chalky hemolymph that failed to clot. Cellular debris and exudates were apparent in the hemolymph of infected animals in late stages of the disease but not in animals with early infections. In heavily infected lobsters, virtually all of the circulating hyalinocytes and semigranulocytes were infected or destroyed (Fig. 1). In the hemolymph, only hyalinocytes and semigranulocytes exhibited alterations due to viral infections; circulating granulocytes were not infected (Figs. 2 to 5). Altered hemocytes were enlarged, possessed densely staining bands of emarginated chromatin, and their nuclei exhibited marked hypertrophy (Figs. 2 to 4 ). Heavily infected cells frequently exhibited eosinophilic Cowdry Type-A inclusions in their nuclei. Connective tissue cells were more noticeably infected in heavy infections (Fig. 3). Pycnotic nuclei, possibly indicative of localized ischemia or apoptosis, were common in moderate and heavy infections (Fig. 3), but karyorrhexis was uncommon.

The following cells and tissues were examined for viral infections: hemocytes, hepatopancreatic tubules, epithelia of the hepatopancreas, fixed phagocytes, gills, gill podocytes, heart, pericardium, connective tissues surrounding the hindgut, the hindgut, and hemopoietic tissues. In heavily infected lobsters, the hepatopancreas exhibited a marked decline in or even absence of reserve inclusion (RI) cells, suggesting a loss of glycogen reserves. RI cells, which vary in relation to molt stage, were abundant in most of the uninfected control animals, but virtually all of the virally infected animals lacked significant reserve inclusions. The hepatopancreas did not exhibit direct lysis, but in some cases, the organ was atrophied as the hemal sinuses were apparently enlarged in relation to the digestive tubules (Figs. $1 \& 2$ ). Indeed, in heavy infections, the fixed phagocytes and blood vessels were obliterated and the surrounding connective tissues were either necrotic or obliterated.

\section{Electron microscopy}

The virus showed a distinct predilection for host hyalinocytes and semigranulocytes (Figs. 5 \& 6). Virions, loose aggregates of virions, and virogenic stroma were diffusely distributed around the inner periphery of the nuclear membrane of the infected hemocytes. Nuclear hypertrophy was extreme with the entire nuclear envelope of many infected cells extended to the limit of the plasma membrane. Heavily infected cells frequently possessed loose matrices or aggregates of virions in the cytoplasm (Figs. 6 \& 12). In heavy infections, virions were free in the hemolymph and occasionally formed loose aggregates within the perforated membranes of the fixed phagocytes in the hemal sinuses of the hepatopancreatic tubules (Fig. 7), a collection point for viral particles in other crustaceans (Johnson 1980).

The viral agent was an icosahedral, presumptive DNA virus (Panulirus argus Virus 1, PaV1) with a nucleocapsid of approximately $182 \pm 9 \mathrm{~nm}(\mathrm{SD})$ and nucleoids approximately $118 \pm 4 \mathrm{~nm}$ (SD) (Fig. 8). The capsid had an electron-lucent inner layer and an electron-dense outer layer on which there were possible external projections when located extracellularly 


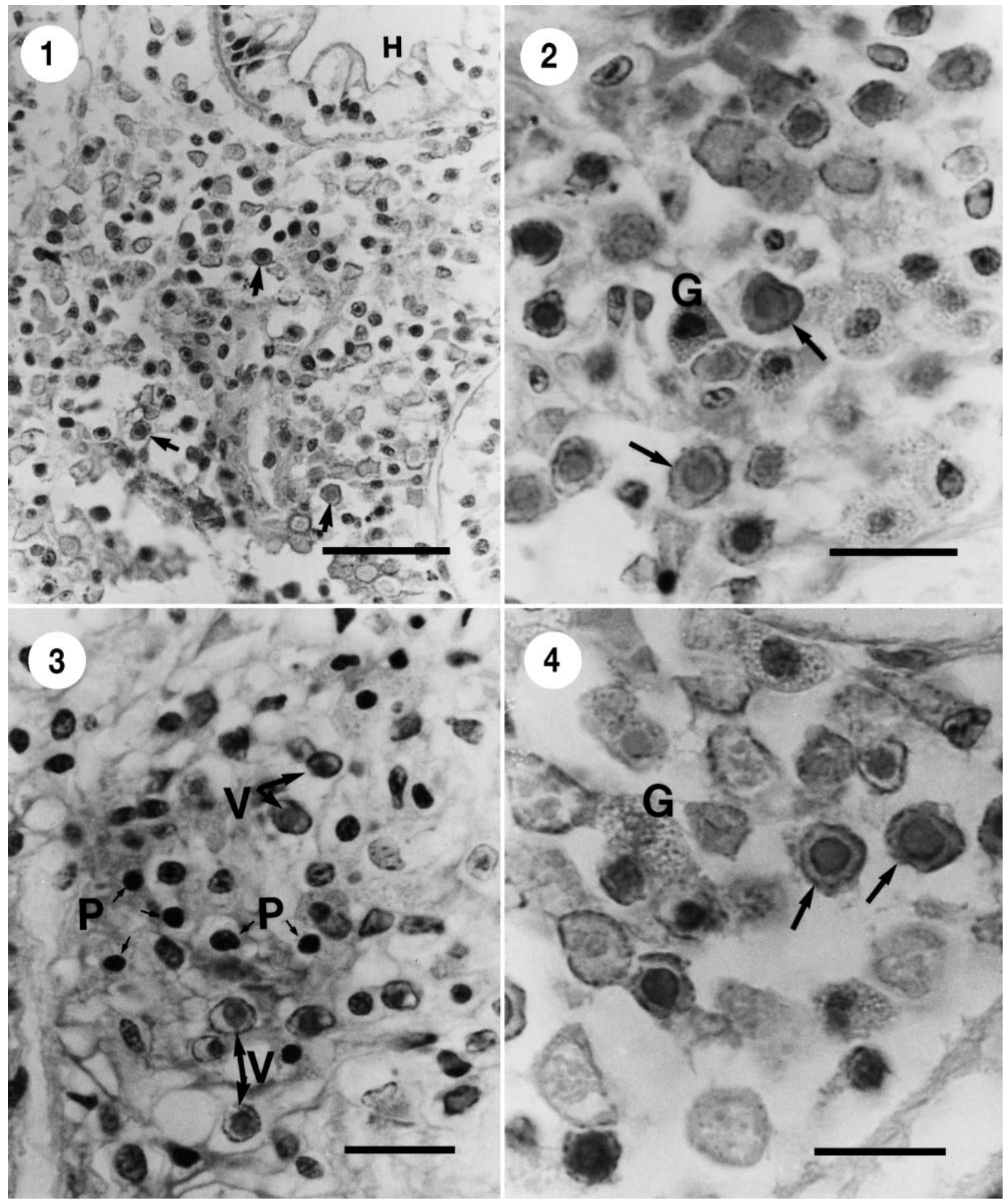

Figs. 1 to 4. Fig. 1. Hemal sinus adjacent to a hepatopancreatic tubule (H). Infected hemocytes (arrows) are abundant. Connec-

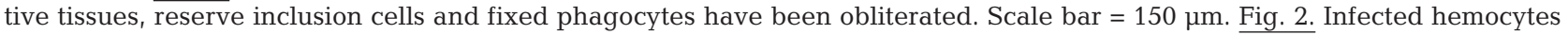
(arrows) showing hypertrophied nuclei with emarginated chromatin and diffuse nucleoplasms. Granulocytes (G) are not infected. Scale bar $=50 \mu \mathrm{m}$. Fig. 3. Infected $(\mathrm{V})$ and pycnotic $(\mathrm{P})$ cells of the soft connective tissues surrounding the hind gut. Scale bar $=$ $50 \mu \mathrm{m}$. Fig. 4. Infected hemocytes (arrows) showing hypertrophied nuclei with emarginated chromatin and diffuse, fibrillar nucleoplasms. Granulocytes (G) were not infected. Scale bar $=50 \mu \mathrm{m}$ 


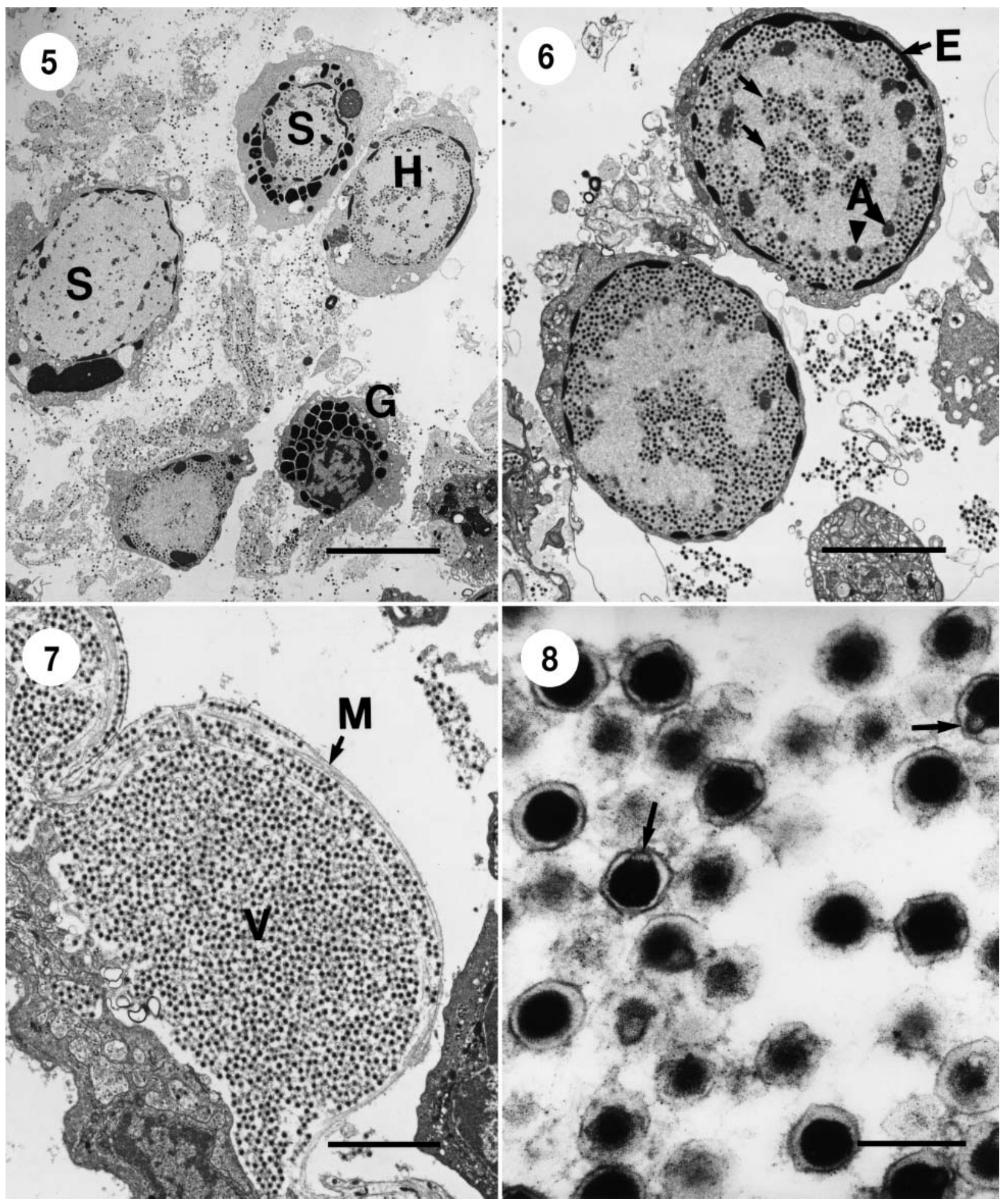

Figs. 5 to 8. Fig. 5. Infected hyalinocytes $(\mathrm{H})$ and semigranulocytes $(\mathrm{S})$ exhibiting hypertrophied nuclei, emarginated chromatin and juxtanuclear mitochondria. Uninfected granulocyte $(\mathrm{G})$ shown with numerous electron-dense granules and normal nucleus. Scale bar $=10 \mu \mathrm{m}$. Fig. 6 . Infected hemocytes showing emarginated chromatin (E), loose aggregates of virions in the nucleoplasm (arrows) and electron-dense whorls within the virogenic stroma (A). Scale bar $=5 \mu \mathrm{m}$. Fig. 7. Matrix of virions (V) aggregated within the perforated membrane of the fixed phagocytes overlying endothelial cells of a hemolymph vessel. Scale bar $=3 \mu \mathrm{m}$. Fig. 8. Detail of virions from Fig. 7 showing icosahedral form, cylinder within the toroid (arrows) of the nucleoid surrounded by a bilayered capsid wall. Scale bar $=3 \mu \mathrm{m}$ 
(Fig. 8). With the sodium cacodylate buffer augmented with sodium chloride and calcium chloride, the nucleoids possessed an internal cylinder surrounded by a subcentric toroid structure similar to the classical toroid of the Herpesviridae. The toroid structure was not apparent when tissues were fixed in the glutaraldehyde with the unmodified sodium cacodylate buffer. Interestingly, there was no apparent tegument, nor an apparent envelope surrounding the nucleocapsids in the cytoplasm, nor was there an envelope surrounding virions outside the cell (e.g. Fig. 8).

Viral assembly of PaV1 occurred entirely within the nucleus of the host cell as indicated by the presence of the fully assembled virions therein (Figs. 9 to 11). Elongated, electron-dense, rod-like elements or tubular structures were observed arising from or adjacent to the emarginated, coalesced chromatin (Fig. 9). Icosahedral nucleocapsids appeared as if budding from the apex of these tubes (Fig. 9), and capsid formation occurred along the tube-like elements or within granular matrices prior to the budding or coalescence of the nucleoid (Fig. 10). Further, whorls of electron-dense material contained short, electron-dense, rod-like elements with adherent capsid material arising from within the whorls (Fig. 11). Viral assembly appeared to occur around these whorls and tubular structures or as a de novo condensation process around uncapsidated nucleoids (Figs. 11 \& 12). Empty capsids were extremely rare if not artifactual in TEM preparations. Unlike the herpes viruses, there was no tegument or envelope formation around the nucleocapsid during migration through the nuclear envelope, nor was there an envelope present during migration through the cytoplasmic membrane (Figs. 8 \& 12). Virions migrated through the nuclear envelope into the cytoplasm and formed loose aggregates in the cytoplasm prior to cell lysis (Fig. 12). In heavy infections, virions occurred freely within the hemal sinuses of the hepatopancreas (Figs. $6 \& 7$ ).

\section{Prevalence and inoculation trials}

Infected lobsters were found throughout nearshore (within $7 \mathrm{~km}$ ) western Florida Bay and infrequently along the Atlantic reef tract adjacent to the Florida Keys. Infections were only found in juvenile lobsters, but few adults were present in the surveys. In 1999, the prevalence of animals with milky hemolymph within individual $25 \mathrm{~m}^{2}$ sites had an overall mean of $17 \%$ (Table 1). At that time, the causative agent of the syndrome had yet to be determined, and the syndrome was likely over-estimated. In summer 2000, the prevalence of animals with overt infection had an overall mean of $8 \%$. In winter 2001, the prevalence of overtly infected animals had a mean of $7 \%$, while during summer 2001, the mean prevalence was $6 \%$.

In inoculation Trial I, all $(\mathrm{n}=10)$ of the inoculated lobsters became infected. One of the uninfected control animals that had been obtained from the field was found to be infected with the disease during the trial and was excluded from further analysis. None of the control animals were otherwise infected nor did any die during the course of the experiments. In inoculation Trial II, 10 of 11 lobsters died. In both trials, mortalities occurred over 30 to $80 \mathrm{~d}$. The disease altered lobster behavior with infected animals exhibiting gross morbidity around 5 to $7 \mathrm{~d}$ prior to death.

\section{DISCUSSION}

We have identified the first naturally occurring pathogenic virus from a lobster. The agent is an unenveloped, nonoccluded, DNA virus (PaV1) with a predilection for the hemocytes and connective tissue cells of juvenile lobsters. Morphologically, PaV1 is unlike members of the Herpesviridae in that the virions are unenveloped, distinctively large (182 nm vs a conserved 115 to $125 \mathrm{~nm}$ ) and without inclusion bodies in the nuclei of infected cells (cf. Minson et al. 2000). However, the assembly of the virion within the host nucleus, the electron-lucent cylindrical core surrounded by an electron-dense toroid and the icosahedral capsid are morphological features shared with the 

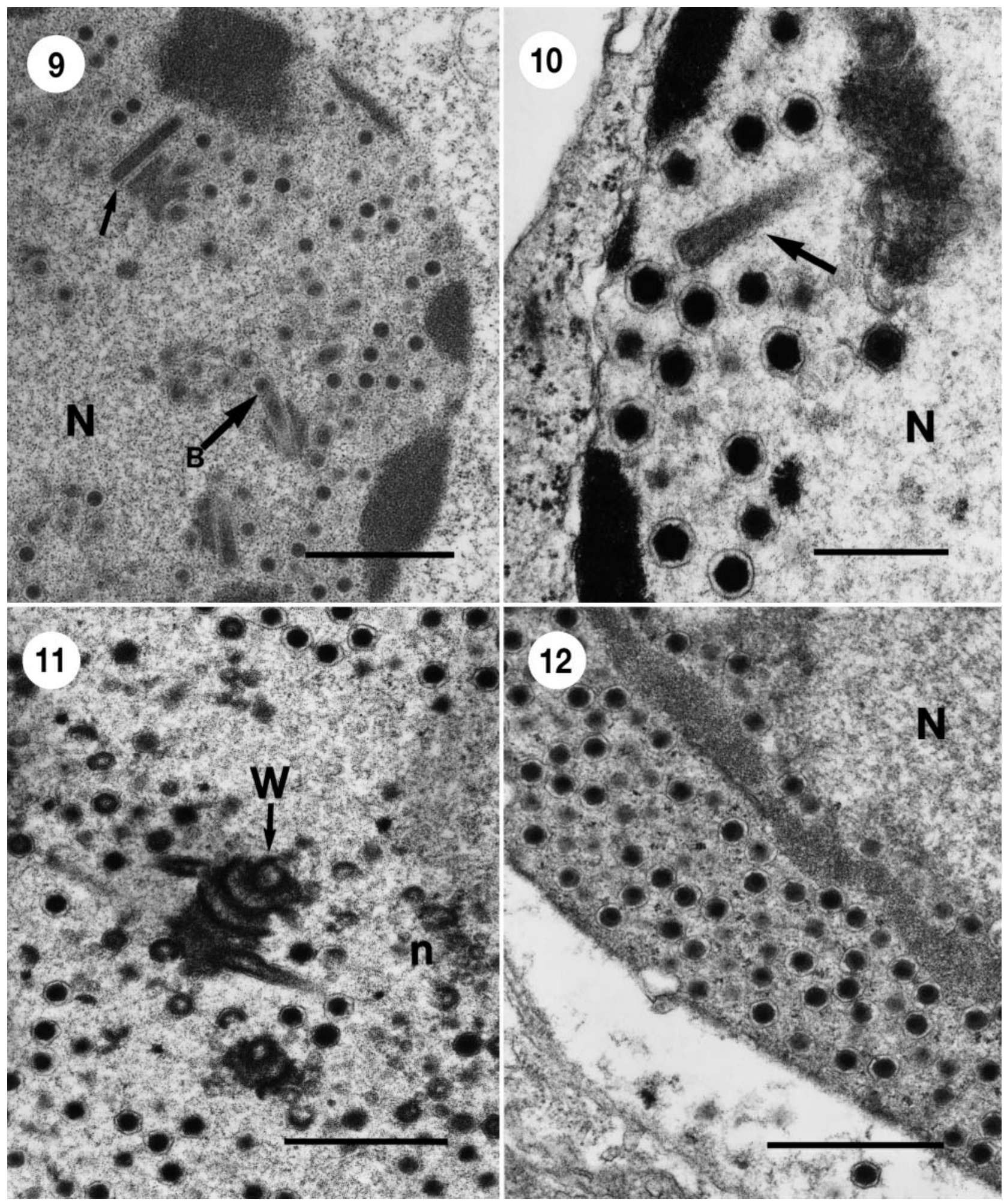

Figs. 9 to 12. Fig. 9. Nucleus (N) of infected hemocyte showing rod-like structures (arrows) with a nucleocapsid possibly budding off (B) from one of the rod-like elements. Scale bar $=3 \mu \mathrm{m}$. Fig. 10. Detail of a rod-like element showing the coalescence of the capsid along a portion of the rod which is arising from the granular matrix. Scale bar $=3 \mu \mathrm{m}$. Fig. 11. Rod-like element shown arising from an intranuclear whorl (W) of electron-dense material. Note the presence of toroids, nucleoids without capsids and the finely granular nuclear matrix. Scale bar $=3 \mu \mathrm{m}$. Fig. 12. Loose aggregate of virions in the cytoplasm adjacent to hypertrophied host nucleus $(\mathrm{N})$. Scale bar $=3 \mu \mathrm{m}$ 
Herpesviridae. PaV1 is somewhat similar to the Iridoviridae with respect to the unenveloped, large icosahedral virions and the accumulation of loose matrices of virogenic stroma in the cytoplasm. However, the assembly of PaV1 entirely within the host nucleus and the presence of the electron-dense toroid are not consistent with the Iridoviridae, which are assembled entirely within the cytoplasm of host cells and have an electron-dense core (Williams et al. 2000).

Morphologically similar viruses have been reported from 3 other crustaceans. A pathogenic herpes-like virus (bifacies virus) infected the hemocytes of blue crabs Callinectes sapidus and was transmissible via cannibalism and injection (Johnson 1976, 1983). It was pathogenic, killing inoculated hosts in $30 \mathrm{~d}$, and reportedly prevalent in $13 \%$ of juvenile crabs (Johnson 1983). Bifacies virus was initially reported as a herpeslike virus (Johnson 1976), but upon better fixation it was shown to differ significantly in morphology from the Herpesviridae by possessing an envelope synthesized within the nucleus, no capsid and an electrondense core region (Johnson 1988). A herpes-like virus was reported in the germinative testicular cells of the mud crab Rhithropanopeus harrisii but it was not known if the virus caused morbidity or mortality (Payen \& Bonami 1979). A pathogenic herpes-like virus was found in the bladder and antennal gland epithelia of Alaskan king crabs Paralithodes platypus, P. camtschaticus and Lithodes aequispina (Sparks \& Morado 1986). The virus was found at relatively high prevalences of 15 to $17 \%$ and was thought to have contributed to major declines in the red king crab fishery in 1982 to 1983 . The hexagonal virus was unenveloped in the nucleus of the host cell but virions were not visualized outside the infected cell (Sparks \& Morado 1986). Further, large, irregular nuclear inclusion bodies were present in host cells infected with the herpeslike virus, a condition not observed in PaV1.

Naturally occurring viral infections have not been reported from lobsters. However, the host range and pathology of an important shrimp virus, white spot syndrome virus (WSSV), has been examined in experimentally infected spiny lobsters. Using a DNA probe specific to WSSV, Chang et al. (1998) detected the virus in the gills, stomach, cuticular epidermis, and hepatopancreas of Panulirus versicolor and P. penicillatus. They did not assess the pathological consequences of infection nor the potential for transmission. Wang et al. (1998) used PCR to detect WSSV in $P$. versicolor, $P$. penicillatus, $P$. ornatus, and $P$. longipes that had been experimentally infected through ingestion of infected shrimp. Although all of the exposed lobsters survived, WSSV was detectable in their tissues at low levels. Experimentally at least, WSSV can have a wide host range in several other decapods (Supamattaya et al. 1998).
We speculate that tubular structures present in the nucleus of infected cells represent aberrant viral assemblies. The nucleoids apparently coalesce along these tubes and capsid elements clearly occur there, but de novo condensation of nucleocapsids occurs more prominently in infected cells. Small fibrillar rods or strands have been reported as intranuclear inclusions in cytomegalovirus (CMV) infections (Cavallo et al. 1981), ranid Herpesvirus 1 (Stackpole \& Mizell 1968) and in herpes-like infections in oysters (Hine \& Thorne 1997, Renault et al. 2000). In CMV, the rods, and the granular nuclear matrix, are the sites of viral DNA synthesis with viral assembly occurring along the edges of the matrix (Fong 1982, Wolber et al. 1988). In herpes-like infections in oysters, the tubes had a smaller diameter than the virions and were frequently adjacent to capsids (Renault et al. 2000). Unlike the Herpesviridae, morphogenesis of the virions of bifacies virus of blue crabs initiates with the formation of a region of the outer and inner envelopes followed by successive condensations of the toroid and core regions prior to completion of the envelope (Johnson 1988).

It is not unusual for viruses to infect the hemocytes of crustaceans. Indeed, at least 6 other viruses primarily infect the hemocytes of crustaceans and at least 6 different viruses can infect hemocytes as well as other tissues (for review see Johnson 1983). However, PaV1 infects the hemocytes differentially by not infecting the granulocytes. WSSV also infected hemocytes differentially, infecting semigranulocytes and granulocytes but not the hyalinocytes of Penaeus merguiensis (Wang et al. 2002). This specificity of susceptible cell type suggests the presence of a receptor recognition system in different subclasses of hemocytes. While this seems intuitive, such has not been reported from crustacean hemocytes to date.

The pathology of infected spiny lobsters shows a marked depletion of reserve inclusions (RIs) in cells of the spongy connective tissues. Glycogen is one of the main storage products in the RIs (Travis 1955, Johnson 1980); it is the substrate for several physiological processes including energy storage and chitin synthesis (e.g. Heath \& Barnes 1970, Stevenson 1985). Glycogen depletion may be a common pathological consequence of microbial and protozoan infections in decapods (Stewart \& Arie 1973, Shields et al. 2003). The loss of RIs with the commensurate loss in glycogen indicates that the energy storage of infected individuals is compromised and that metabolic exhaustion coupled with ischemia from anaerobic metabolism is a likely cause of death for infected lobsters.

Unfortunately, current fishing practices may accelerate the transmission and spread of this disease. Commercial fishermen use live juvenile lobsters in traps as 'bait' (i.e. a social attractant) for larger adults. The 
close proximity of lobsters confined in traps and the confinement of juveniles by the hundreds in live-wells, along with the physiological stresses induced by such practices, could facilitate the spread of infectious diseases. Transport of juvenile lobsters throughout the fishing grounds could also facilitate the spread of pathogens. Given the notoriety of viral infections in shrimp (WSSV, YHV, TSV; for review see Flegel 1997, Lightner \& Redman 1998), the pathology of similar infections in blue and king crabs, and our initial data, we believe that further characterization of this virus is warranted.

Acknowledgements. Mark Butler graciously contributed in many and various ways. We thank the staff of FWC for the use of laboratory space, aquaria, SPA data and help with the initial reef survey. Patrice Mason provided skilled technical support with the TEM. Two reviewers provided additional insights. This work was supported in part by NOAA, Saltonstall-Kennedy Program Grant No. NA17FD2366 and NSF Biological Oceanography Program Grant No. OCE-0136894. This is VIMS Contribution No. 2481.

\section{LITERATURE CITED}

Alderman DJ (1973) Fungal infection of crawfish (Palinurus elephas) exoskeleton. Trans Br Mycol Soc 61:595-597

Bach SD, Beardsley GL (1976) A disease of the Florida spiny lobster. Sea Frontiers 22:52-53

Bobes R, Diaz J, Diaz E (1988) Aislamiento e identificacion de Aerococcus viridans var. homari en la langosta Panulirus argus con sintomas de septicemia. Rev Invest Mar 9: 97-103

Booth JD (1988) Rock lobster farming in New Zealand: problems and possibilities. In: Proc. AQUANZ '88, National Conference on Aquaculture, Wellington, NZ. NZ Fish Occ Publ \#4, NZ Ministry Agriculture \& Fisheries, p 100-104

Butler MJ IV, Hunt JH, Herrnkind WF, Matthews T and 5 others (1995) Cascading disturbances in Florida Bay, USA: cyanobacteria blooms, sponge mortality, and implications for juvenile spiny lobster Panulirus argus. Mar Ecol Prog Ser 129:119-125

Campbell A, Gibson R, Evans LH (1989) A new species of Carcinonemertes (Nemertea: Carcinonemertidae) ectohabitant on Panulirus cygnus (Crustacea: Palinuridae) from Western Australia. Zool J Linn Soc 95:257-268

Cavallo T, Graves K, Cole NL, Albrecht T (1981) Cytomegalovirus: an ultrastructural study of the morphogenesis of nuclear inclusions in human cell culture. J Gen Virol 56:97-104

Chang PS, Chen HC, Wang YC (1998) Detection of white spot syndrome associated baculovirus in experimentally infected wild shrimp, crab and lobsters by in situ hybridization. Aquaculture 164:233-242

Chong YC, Chao TM (1986) Septicemias of marine crabs and shrimp. In Maclean IL, Dizon LB, Hosillos LV (eds) The first asian fisheries forum. Asian Fisheries Society, Manila, Philippines, p 331-332

Deblock S, Williams A, Evans LH (1990) Contribution à l'etude des Microphallidae Travassos 1920 (Trematoda): description de Thulakiotrema genitale n. gen., n. sp., metacercaire parasite de langoustes australiennes. Bull Mus Natn Hist Nat Paris 12:563-576
Dennis DM, Munday BL (1994) Microsporidiosis of palinurid lobsters from Australian waters. Bull Eur Assoc Fish Path 14:16-18

Diggles BK, Moss GA, Carson J, Anderson CD (2000) Luminous vibriosis in rock lobster Jasus verreauxi (Decapoda: Palinuridae) phyllosoma larvae associated with infection by Vibrio harveyi. Dis Aquat Org 43:127-137

Evans LH, Brock JA (1994) Diseases of spiny lobster. In: Phillips BF, Cobb JS, Kittaka J (eds) Spiny lobster management. Blackwell, Oxford, p 461-471

Evans LH, Jones JB, Brock JA (2000) Diseases of spiny lobster. In: Phillips BF, Kittaka J (eds) Spiny lobsters: fisheries and culture. Blackwell, Oxford, p 586-600

Factor JR, Naar M (1985) The digestive system of the lobster, Homarus americanus: I. Connective tissue of the digestive gland. J Morphol 184:311-321

Flegel TW (1997) Major viral diseases of the black tiger prawn (Penaeus monodon) in Thailand. World J Microbiol Biotechnol 13:433-442

Fong CKY (1982) Ultrastructural localization of cytomegalovirus DNA synthesis in infected guinea-pig cells. J Gen Virol 60:235-245

Heath JR, Barnes H (1970) Some changes in biochemical composition with season and during the moulting cycle of the common shore crab, Carcinus maenas. J Exp Mar Biol Ecol 5:199-233

Herrnkind WH, Butler MJ IV, Hunt JH, Childress M (1997) The role of physical refugia: implications from a mass sponge die-off in a lobster nursery. Mar Freshw Res 48:759-770

Hine PM, Thorne T (1997) Replication of herpes-like viruses in haemocytes of adult flat oysters Ostrea angasi: an ultrastructural study. Dis Aquat Org 29:189-196

Humason GL (1979) Animal tissue techniques, 4th edn. WH Freeman, San Francisco

Iversen ES, Beardsley GL (1976) Shell disease in crustaceans indigenous to South Florida. Progress Fish-Cultur 38: 195-196

Johnson PT (1976) A herpeslike virus from the blue crab, Callinectes sapidus. J Invertebr Pathol 27:419-420

Johnson PT (1980) Histology of the blue crab, Callinectes sapidus: a model for the Decapoda. Praeger, New York

Johnson PT (1983) Diseases caused by viruses, rickettsiae, bacteria, and fungi. In: Provenzano AJ (ed) The biology of crustacea: pathology, Vol 6. Academic Press, New York, p 1-78

Johnson PT (1988) Development and morphology of an unusual nuclear virus of the blue crab Callinectes sapidus. Dis Aquat Org 4:67-75

Kitancharoen N, Hatai K (1995) A marine oomycete Atkinsiella panulirata sp. nov. from phyllosoma of spiny lobster, Panulirus japonicus. Mycoscience 36:97-104

Kittaka J, Abrunhosa FA (1997) Characteristics of palinurids (Decapoda: Crustacea) in larval culture. Hydrobiologia 358:305-311

Lightner DV, Redman RM (1998) Strategies for the control of viral diseases of shrimp in the Americas. Fish Pathol 33: 165-180

McAleer R (1983) Black shell disease of the western rock lobster caused by Fusarium solani. Proc 8th Int Soc Human Anim Mycol, Massy Univ, Palmerston North, NZ, p 378-382

Minson AC, Davison A, Eberle R, Desrosiers RC and 5 others (2000) Family Herpesviridae. In: van Regenmortel MHV, Fauqet CM, Bishop DHL, Carstens EB and 7 others (eds) Virus taxonomy: classification and nomenclature of viruses. Seventh Report of the International Committee on Taxonomy of Viruses. Academic Press, San Diego, p 203-225 
Payen GG, Bonami JR (1979) Mise en évidence de particules d'allure virale associées aux noyaux des cellules mésodermiques de la zone germinative testiculaire du crabe Rhithropanopeus harrisii (Gould) (Brachyoure, Xanthidae). Rev Trav Inst Pêches Marit 43:361-365

Renault T, LeDeuff R-M, Chollet B, Cochennec N, Gérard A (2000) Concomitant herpes-like virus infections in hatchery-reared larvae and nursery-cultured spat Crassostrea gigas and Ostrea edulis. Dis Aquat Org 42:173-183

Schapiro HC, Mathewson JH, Steenbergen JF, Kellog S, Ingram C, Nierengarten G, Rabin H (1974) Gaffkemia in the California spiny lobster, Panulirus interruptus: infection and immunization. Aquaculture 3:403-408

Shields JD, Kuris AM (1990) Carcinonemertes wickhami n. sp. (Nemertea), an egg predator on the California lobster, Panulirus interruptus. Fish Bull 88:279-287

Shields JD, Scanlon C, Volety A (2003) Aspects of the pathophysiology of blue crabs, Callinectes sapidus, infected with the parasitic dinoflagellate Hematodinium perezi. Bull Mar Sci 72:519-535

Sindermann CJ, Rosenfield A (1967) Principal diseases of commercially important marine bivalve Mollusca and Crustacea. Fish Bull 66:335-385

Sordi M (1958) Micosi dei Crostuacei decapodi marini. Riv Parassitol 19:131-137

Sparks AK, Morado JF (1986) A herpes-like virus disease in the blue king crab Paralithodes platypus. Dis Aquat Org 1: $115-118$

Stackpole CW, Mizell M (1968) Electron microscopic observations on herpes-type virus-related structures in the frog renal adenocarcinoma. Virology 36:63-72

Stevenson JR (1985) Dynamics of the integument. In: Bliss DE, Mantel LH (eds) The biology of the Crustacea: integu-

Editorial responsibility: Timothy Flegel,

Bangkok, Thailand ment, pigments, and hormonal processes, Vol 9. Academic Press, Orlando, FL, p 1-42

Stewart JE, Arie B (1973) Depletion of glycogen and adenosine triphosphate as major factors in the death of lobsters (Homarus americanus) infected with Gaffkya homari. Can J Microbiol 19:1103-1110

Supamattaya K, Hoffmann RW, Boonyaratpalin S, Kanchanaphum P (1998) Experimental transmissions of white spot syndrome virus (WSSV) from black tiger shrimp Penaeus mondon to the sand crab Portunus pelagicus, mud crab Scylla serrata and krill Acetes sp. Dis Aquat Org 32: 79-85

Travis DF (1955) The molting cycle of the spiny lobster, Panulirus argus Latreille. II. Pre-ecdysial histological and histochemical changes in the hepatopancreas and integumental tissues. Biol Bull 108:88-112

Wang YC, Lo CF, Chang PS, Kou GH (1998) Experimental infection of white spot baculovirus in some cultured and wild decapods in Taiwan. Aquaculture 164:221-231

Wang YT, Liu W, Seah JN, Lam CS, Xiang JH, Korzh V, Kwang J (2002) White spot syndrome virus (WSSV) infects specific hemocytes of the shrimp Penaeus merguiensis. Dis Aquat Org 52:249-259

Williams T, Chinchar G, Darai G, Hyatt A, Kalmakoff J, Seligy V (2000) Family Iridoviridae. In: van Regenmortel MHV, Fauqet CM, Bishop DHL, Carstens EB and 7 others (eds) Virus taxonomy: classification and nomenclature of viruses. Seventh Report of the International Committee on Taxonomy of Viruses. Academic Press, San Diego, p 167-182

Wolber RA, Beals TF, Lloyd RV, Hunein FM (1988) Ultrastructural localization of viral nucleic acid by in situ hybridization. Lab Invest 59:144-151

Submitted: May 28, 2002; Accepted: December 31, 2003 Proofs received from author(s): May 3, 2004 